Tersedia Secara Online di

\title{
Beton Fc' 21,7 Mpa Menggunakan Agregat Kasar Biji Genitri
}

\author{
M. S. Bahrudin ${ }^{1 *}$, A. I. Candra ${ }^{2}$, S. Winarto ${ }^{3}$, \\ ${ }^{1 * 23}$ Fakultas Teknik, Universitas Kadiri. \\ Email : 1* barons0420@gmail.com.
}

\begin{tabular}{ll} 
A R T I C L E & I N F O \\
\hline Article history: & \\
Artikel masuk & $: 05-10-2020$ \\
Artikel revisi & $: 08-10-2020$ \\
Artikel diterima & $: 12-10-2020$ \\
\hline
\end{tabular}

Keywords :

Concrete Fc' 21,7 Mpa, Genitri Seeds, Compressive Strength, Lightweight Concrete

Style IEEE dalam mensitasi artikel ini:

[13]

A. Faslih, I. Kadir, and M. Z. Umar, "Practical production of lightweight concrete floor tiles," IOP Conf. Ser. Earth Environ. Sci., vol. 419, no. 1, 2020, doi: 10.1088/1755-1315/419/1/012150.

\begin{abstract}
A B S T R A C T
Concrete in technological development has progressed very rapidly, so that it is able to open ideas in the use of organic materials as an alternative material for concrete. Genitri seeds are an organic material that can be used as an alternative to the building blocks of concrete. Genitri seeds have very good hardness and have a light volume weight so that they can reduce the large structure weight due to the weight of the concrete itself. The research method used in this study is an experimental method with genitri seeds as a mixture of coarse aggregate in concrete. This study aims to determine how much influence the compressive strength, slump value, volume weight, absorption, using a mixture of genitri seeds with a percentage of 5\%, 10\%, $15 \%$ of the weight of coarse aggregate. The results showed that the highest compressive strength was obtained by the addition of 5\% genitri seeds, namely 20.75Mpa with an average slump value of 5.2. In the absorption test, the value of $1 / 4$ hour 0.0401 hour 0.022 4 hours 0.00624 hours 0.002 was obtained.
\end{abstract}

\section{A B S T R A K}

Beton dalam perkembangan teknologi mengalami kemajuan yang sagat pesat, sehingga mampu membuka pemikiran dalam pemanfaatan material organik sebagai bahan alternatif penyusun beton. Biji genitri merupakan salah satu bahan organik yang dapat digunakan sebagai alternatif material penyusun beton. Biji genitri memiliki kekerasan yang sangat baik dan memiliki berat volume yang ringan sehingga dapat mengurangi berat struktur yang besar akibat beban dari berat beton itu sendiri. Metode penelitian yang digunakan pada penelitian ini adalah metode eksperimental dengan biji genitri sebagai bahan campuran agregat kasar pada beton. Penelitian ini bertujuan untuk mengetahui seberapa besar pengaruh terhadap kuat tekan, nilai slump, berat volume, absorpsi, dengan menggunakan bahan campuran biji genitri dengan persentase $5 \%, 10 \%, 15 \%$ dari berat agregat kasar. Dari hasil penelitian menunjukkan bahwa kuat tekan tertinggi diperoleh dengan penambahan biji genitri sebesar $5 \%$ yaitu $20,75 \mathrm{Mpa}$ dengan nilai slump rata-rata 5,2. Pada pengujian absorpsi diperoleh nilai $1 / 4$ jam 0,040 1 jam 0,022 4 jam 0,00624 jam 0,002 . 


\section{Pendahuluan}

Kemajuan pembangunan dalam bidang struktur terus mengalami peningkatan yang sangat pesat, misalnya gedung, jembatan, jalan, bendungan[1]. Semua pekerjaan konstruksi pasti menggunakan konstruksi beton, dan beton adalah merupakan salah satu struktur terpenting pada bangunan. Beton juga sebagai bahan konstruksi yang banyak digunakan pada struktur bangunan dan banyak diminati di berbagai kalangan karena memiliki banyak kelebihan yang terdapat pada beton[2]' seperti tahan terhadap kebakaran dan tahan aus, memiliki mutu kuat tekan yang bagus. Beton memiliki sifat tahan terhadap pengkaratan / pembusukan terhadap situasi di sekitar lingkungan, dan pelaksanaanya mudah untuk dibentuk sesuai dengan bentuk yang dikehendaki.[3]

Bahan dari beton juga mudah untuk di dapatkan di bandingkan dengan bahan lainnya, karena harga bahan yang relatif terjangkau dan menggunakan bahan dasar dari lokal. Berdasarkan kuat tekannya, mutu beton dibagi menjadi 3 jenis, yaitu beton mutu rendah / low strength concrete, beton mutu sedang / medium strength concrete dan beton mutu tinggi / high strength concrete [4]. Beton merupakan hasil dari pencampuran semen portland atau semen hidraulik lain, agregat halus, agregat kasar, dan air. Sejalan dengan perkembangan teknologi di bidang beton, telah membuka pemikiran dalam pemanfaatan material organik sebagai bahan alternatif penyusun beton.[5] Penggunaan material organik bertujuan untuk mengurangi berat struktur yang besar akibat beban dari berat beton itu sendiri selain dari beban-beban yang lain[6].

Salah satu material organik yang dapat dimanfaatkan adalah biji genitri. Pada tingkat kekerasan biji genitri yang bagus perlu dimanfaatkan sebagai bahan campuran agregat kasar pada beton. Tujuan dari penelitian ini yaitu mengetahui bagaimana pengaruh biji genitri dengan presentase tertentu nilai slump, absorpsi, berat volume, dan kuat tekan beton .

\section{Studi Literatur}

Berdasarkan penelitian yang telah dilakukan Agata dan selaras dengan topik penelitian ini mengenai Rekayasa job Mix beton ringan menggunakan hydroton dan master ease 5010 pada tahun 2018[7], menunjukkan bahwa beton ringan masih memiliki tingkat efisiensi lebih jika di bandingkan dengan beton konvensional pada umumnya, dan selanjutnya penelitian yang telah dilakukan oleh Sigit mengenai pemanfaatan serat ijuk sebagai material campuran dalam beton untuk meningkatkan kemampuan beton menahan beban tekan pada tahun 2017[2], menunjukkan bahwa perubahan berat beton yang terjadi pada beton berserat ijuk menjadi lebih 
ringan, yaitu $2.243 \mathrm{gr} / \mathrm{cm}$, dan yang terakhir penelitian mengenai kuat uji tekan beton dengan memanfaatkan limbah beton yang tidak terpakai pada tahun 2017, menunjukkan bahwa kuat tekan beton yang di hasilkan dari rata-rata campuran bahan limbah beton yang sudah tidak terpakai 16,977 Mpa[4].

\subsection{Landasan Teori}

Beton merupakan sebuah komponen sangat penting dalam dunia konstruksi [8]. Beton adalah campuran yang terdiri dari sebagian besar agregat yang dicampur dengan pasta / mortar yang terbuat dari semen dan air, sehingga membentuk massa seperti batuan [9][10]. Beton juga memiliki massa jenis yang relatif tinggi, 2,4t / m3, mempengaruhi jumlah beban yang dapat ditopang oleh suatu struktur bangunan.[11] Bentuk paling umum dari beton adalah beton semen portland, yang biasanya terdiri dari campuran semen, air dan bahan mineral lainya yang berupa agregat halus (pasir) dan agregat kasar (koral)[7]. Pada saat ini beton merupakan bahan kontruksi pada bangunan yang paling banyak dipakai di seluruh dunia.

Mutu kuat tekan beton sangat mempengaruhi terutama dalam perencanaan konstruksi [12]. Beton selalu ditetapkan dahulu mutu betonnya. Perhitungan yang dilakukan berdasarkan pada mutu beton yang telah ditentukan. Mutu beton ini akhirnya menentukan ukuran daripada balok-balok, kolom-kolom, plat-plat, dinding-dinding beton. Sudah tentu perhitungan dengan mutu beton yang lebih rendah akan menghasilkan ukuran yang lebih besar bila dibandingkan dengan hasil perhitungan dari mutu beton yang lebih tinggi.

\subsubsection{Kelebihan beton}

Salah satu kelebihan yang terdapat pada beton adalah beton tahan terhadap suhu tinggi, bahan-bahan beton mudah untuk di dapatkan di bandingakan dengan bahan lainnya[13].

\subsubsection{Kekurangan beton}

Salah satu kekurangan dari beton adalah beton juga dapat mengembang dan menyusut ketika terjadi perubahan pada suhu, sehingga perlu dibuat dilatasi expansion joint agar supaya mencegah dari terjadinya retak akibat dari berubahnya suhu.

\subsubsection{Jenis-jenis beton :}

Berikut adalah jenis-jenis beton :

1. Beton ringan : beton yang agregat kasarnya diganti dengan agregat ringan.

2. Beton siklop : beton yang menggunakan ukuran agregat yang relative besar. 
3. Beton non pasir : beton yang dibuat tanpa menggunakan pasir, jadi hanya menggunakan air, semen, dan kerikil saja.

4. Beton prategang: jenis beton ini sama dengan beton bertulang, perbedaannya adalah batang baja yang dimasukkan ke dalam beton ditegangkan dahulu.

5. Beton bertulang: beton yang dimasuki batang baja pada bagian tariknya ini disebut beton bertulang.[14]

6. Beton hampa : beton jenis ini diaduk dan dituangkan serta dipadatkan sama dengan beton biasanya, tetapi setelah beton tercetak padat lalu air sisa reaksi disedot menggunakan cara yang khusus. Seperti dengan menggunakan metode vakum, sehingga air yang tertinggal hanya air yang digunakan untuk reaksi dengan semen, sehingga beton yang diperoleh sangat kuat.

7. Beton massa : beton yang dituang dalam volume besar yaitu perbandingan antara volume dan permukaannya besar.[15]

8. Beton serat : beton yang terdiri dari beton biasa dan bahan lain yang berupa serat.

9. Fero semen : suatu bahan campuran yang didapatkan dengan cara menambahkan ortar semen pada suatu tulangan yang berupa anyaman kawat baja.

10. Beton pracetak : beton biasa dicetak di tempat, namun dapat pula dicetak di tempat lain, fungsi dari pencetakan ditempat lain adalah untuk memperoleh mutu yang lebih baik. Selain itu digunakan bila tempat pembuatan beton sangat terbatas sehingga sulit menyediakan tempat percetakan dan perawatan betonnya.

\subsection{Bahan-Bahan Penyusun Beton}

Penyusun beton merupakan hasil dari pencampuran bahan-bahan yang terdiri dari pasir, batu pecah, jika diperlukan bahan tambah (admixture) untuk mengubah sifat-sifat tertentu dari beton, atau bahan senyawa lainnya dengan menambahkan semen secukupnya yang berfungsi sebagai perekat bahan susun beton, dan air berfungsi sebagai bahan pembantu reaksi kimia selama proses pengerasan dan perawatan beton berlangsung [16].

- Semen Portland semen hidrolis yang dihasilkan dengan cara menggiling terak semen portland, terutama yang terdiri dari kalsium silikat yang bersifat hidrolis.[17]

- Air merupakan bahan dasar pembuatan beton yang sanagat penting.

- Agregat didefinisikan sebagai material granular, misalnya pasir kerikil, batu pecah, dan kerak tungku besi.(SNI 03-2847-2002). Agregat ada 2 jenis yaitu: agregat kasar yang merupakan agregat yang mempunyai ukuran butir antara 5,00 mm sampai $40 \mathrm{~mm}$ dan 
agregat halus merupakan agregat yang mempunyai ukuran butir maksimum sebesar 5,00 $\mathrm{mm}$.

- Biji genitri merupakan termasuk dalam familli Elaeocarpacea. Tanaman ganitri dapat menghasilkan biji dengan kulit biji sangat keras, berukir, berwarna coklat, dan berdiameter antara $1-1,5 \mathrm{~cm} .[18]$

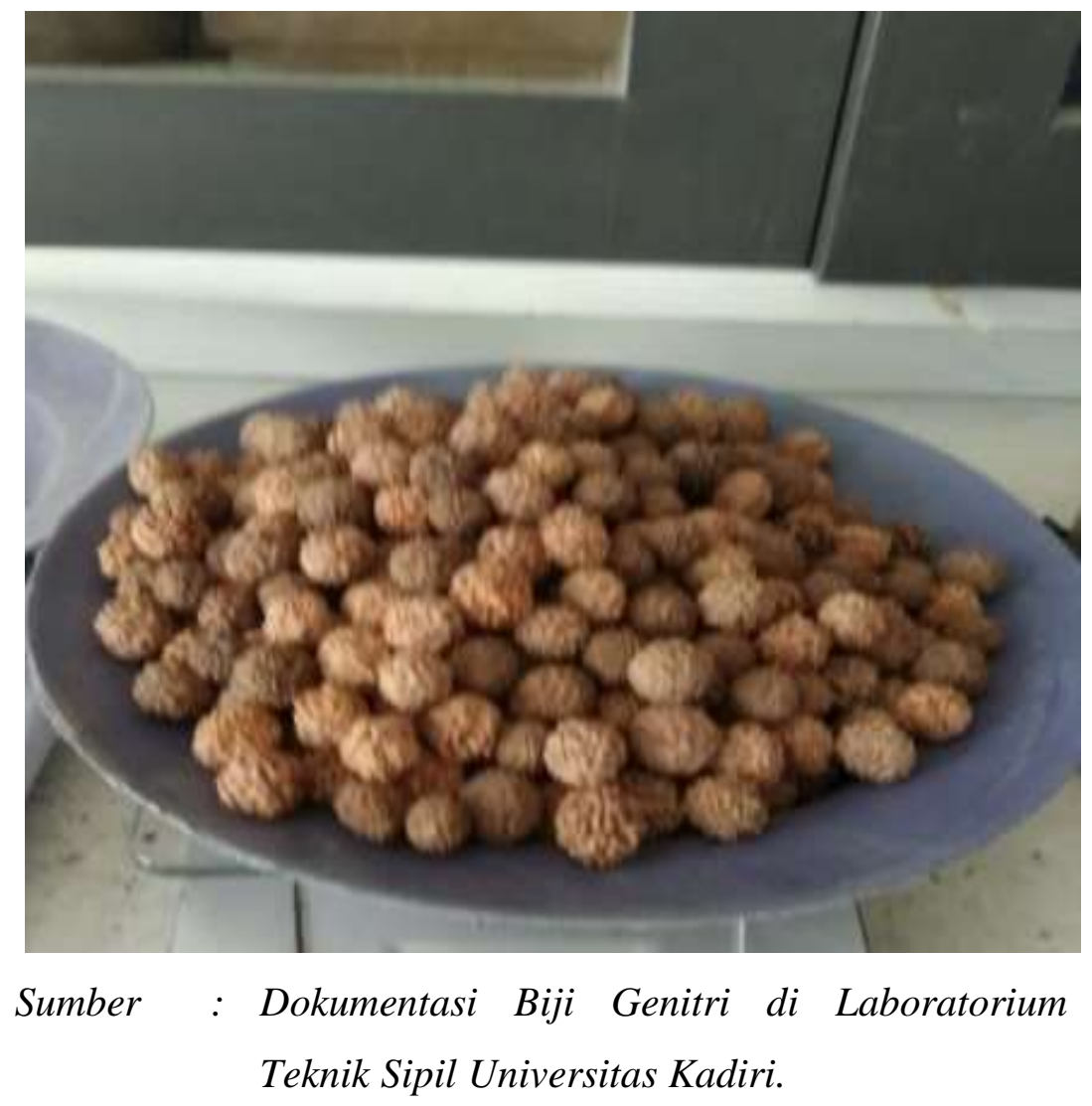

Gambar 1. Biji Genitri.

\subsection{Pengujian Slump}

Slump merupakan tes yang berfungsi untuk mengetahui nilai kekentalan adukan beton menggunakan alat tes yang dinamakan kerucut abram. Fungsi dari tes ini adalah untuk mengetahui kualitas dari beton dan untuk mengetahui apakah adukan beton tersebut memiliki workability yang baik atau tidak.

\subsection{Berat Volume}

Pengujian berat volume beton dilakukan sebelum pembebanan benda uji silinder. Berat volume beton diketahui dengan cara menimbang dan mengukur tinggi serta diameter benda uji, sehingga didapatberat dan volume benda uji tersebut. 


\subsection{Absorpsi}

Absorpsi merupakan kemampuan air untuk melalui rongga kapiler melalui permukaan hingga lapisan dalam pada beton ketika bersentuhan dengan air. Penelitian absorpsi diukur dengan menghitung persentase antara perbedaan massa dari kondisi kering sampai kondisi SSD (saturated surface dry). Pengujian dilakukan berdasarkan ASTM C-1585 [19] [20]

\subsection{Kuat Tekan}

Kekuatan tekan beton adalah besarnya beban per satuan luas yang dapat menyebabkan benda uji beton hancur jika di bebani dengan gaya tekan tertentu. Pada dasarnya karakteristik yang paling penting dalam kualitas beton dibandingkan dengan sifat-sifat lainnya. Kekuatan tekan beton ditentukan oleh susunan rasio semen, agregat kasar dan halus, air [21].

\section{Metodologi Penelitian}

Metode yang dilakukan adalah metode eksperimental dengan biji genitri sebagai campuran agregat kasar dengan persentase 5\%, 10\%, 15\% dari berat agregat kasar . Benda uji yang digunakan berbentuk silinder dengan ukuran $15 \times 30 \mathrm{~cm}$. Pada tiap variasi terdapat 4 sampel yang digunakan . Pengujian kuat tekan dilakukan saat umur beton 28 hari . 


\subsection{Alur Penelitian}

Alur penelitian diuraikan pada bagan berikut :

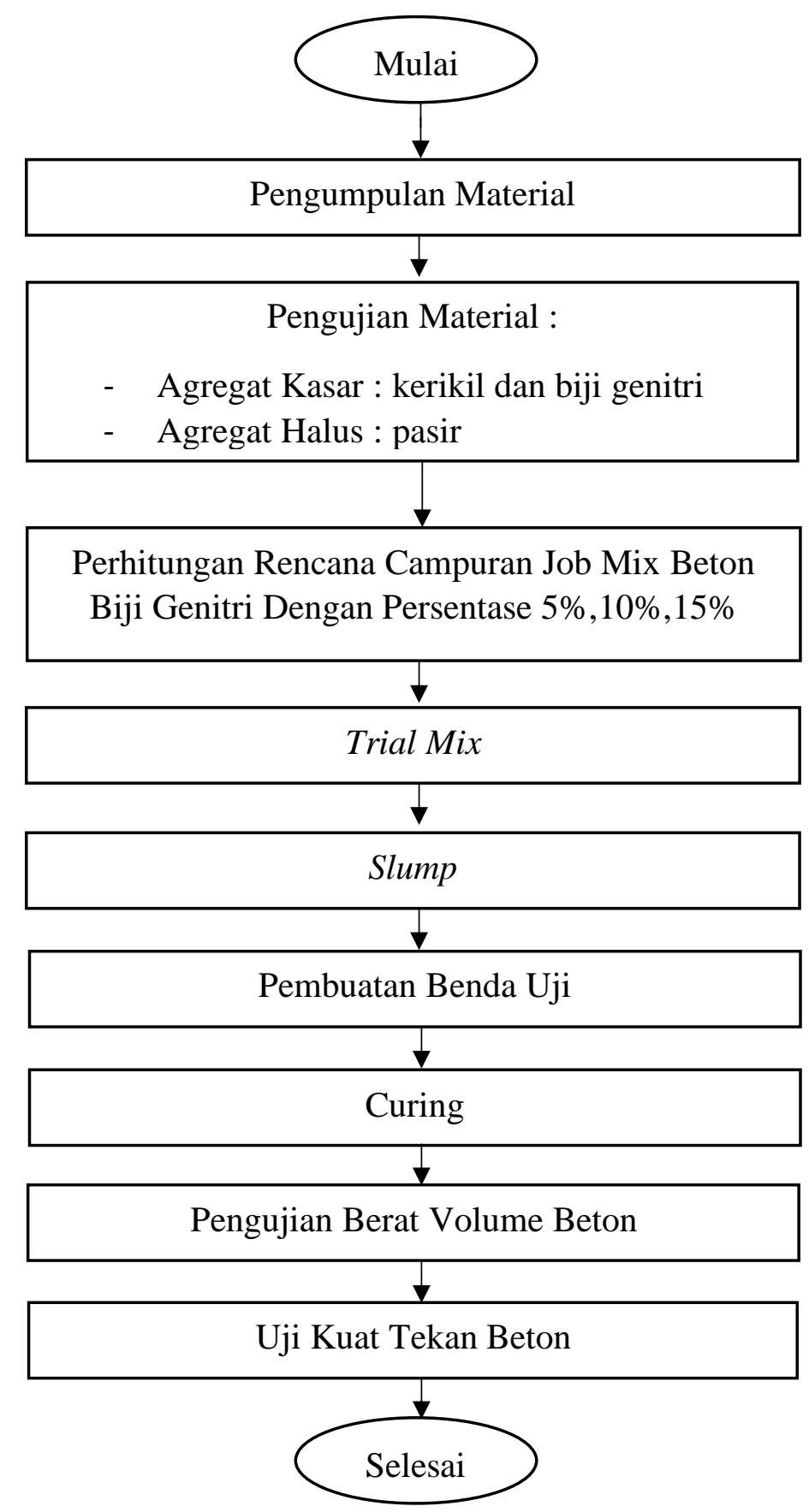

Sumber : Analisa Alur Penelitian.

Gambar 2. Alur Penelitian.

Penelitian dimulai dengan mempersiapkan bahan meliputi agregat kasar (koral, biji genitri), halus (pasir), air, dan semen. Agregat kasar dan halus di oven hingga kadar air hilang. Selanjutnya agregat harus lolos ayakan yang sudah ditentukan, agregat kasar 1 1/2, 3/4, 1/2, dan 3/8 dan halus 4,8,16,30, dan 40. Kemudiann pengujian agregat kasar menggunakan alat abrasi (los angeles) sesuai dengan standart yang telah di tentukan, dan pengujian kadar lumpur dari agregat 
kasar dan halus, selanjutnya merencanakan perhitungan job mix beton. Setelah menghitung job mix melakukan trial mix dengan alat molen lalu menentukan konsistesi / kekakuan menggunakan slump kemudian membuat benda uji dengan cetakan silinder ukuran $15 \mathrm{~cm} \mathrm{x}$ $30 \mathrm{~cm}$, selanjutnya melakukan proses curing selama 28 hari, setelah itu melakukan pengujian berat volume beton, yang terakhir uji kuat tekan beton menggunakan alat Compression Testing Machine (CTM).

Tabel 1. Perhitungan Rencana Campuran Beton.

Kebutuhan beton per silinder

\begin{tabular}{cccccccc} 
Variasi & Kode & Jumlah & Semen & Pasir & Kerikil & Air & Biji \\
Presentase & Benda Uji & Sampel & kg & Kg & kg & L & Genitri \\
\hline $0 \%$ & BT-N & 3 & 2,03 & 3,67 & 5,51 & 1,14 & 0,00 \\
$5 \%$ & BT-Mix & 3 & 2,03 & 3,67 & 5,51 & 1,14 & 0,28 \\
$10 \%$ & BT-Mix & 3 & 2,03 & 3,67 & 5,51 & 1,14 & 0,55 \\
$15 \%$ & BT- Mix & 3 & 2,03 & 3,67 & 5,51 & 1,14 & 0,83 \\
Jumlah & & 12 & & & & & \\
\end{tabular}

Sumber : Analisa Perhitungan Rencana Campuran Beton.

\section{Hasil dan Diskusi}

Sebelum melakukan pembuatan benda uji beton, harus melakukan pengujian terlebih dahulu terhadap bahan-bahan penyusun beton, dilanjutkan dengan pembahasan hasil dari benda uji beton. Adapun data hasil dari pengujian akan di susun menggunakan tabel dan grafik mulai dari pengujian bahan hingga pengujian dari benda uji beton.

\subsection{Hasil Pengujian Material}

\subsubsection{Hasil Pengujian Agregat Halus}

Pengujian terhadap agregat halus yang dilakukan dalam penelitian ini meliputi pengujian kadar air, kadar lumpur, berat jenis dan penyerapan, berat volume, modulus dan analisa saringan. Hasil-hasil pengujian tersebut disajikan dalam Tabel 2. 
Tabel 2. Spesifikasi Hasil Agregat Halus.

\begin{tabular}{clccc}
\hline No & \multicolumn{1}{c}{ Karakteristik } & Standar & Hasil Uji & Keterangan \\
\hline 1 & Kadar Air & $2 \%-5 \%$ & $4,30 \%$ & Memenuhi \\
2 & Kadar Lumpur & Maks 5\% & $1,40 \%$ & Memenuhi \\
3 & Berat Volume & & & \\
& a. Lepas & $1.6-1.9 \mathrm{~kg} / \mathrm{liter}$ & 1,62 & Memenuhi \\
& b. Padat & $1.6-1.9 \mathrm{~kg} / \mathrm{liter}$ & 1,73 & Memenuhi \\
4 & Absropsi & Maks $2 \%$ & 0,6 & Memenuhi \\
5 & Berat Jenis & & & \\
& a. Berat jenis Curah & $1.6-3.3$ & 2,82 & Memenuhi \\
& b. Berat jenis Kering Permukaan & $1.6-3.4$ & 2,84 & Memenuhi \\
& c. Berat jenis Semu & $1.6-3.8$ & 2,87 & Memenuhi \\
6 & Modulus Halus Butir & $1.5-3.8$ & 3,43 & Memenuhi \\
\hline
\end{tabular}

Sumber : Analisa Perhitungan Spesifikasi Hasil Agregat Halus.

Dari hasil tabel diatas menunjukkan bahwa nilai karakteristik dari agregat halus rata-rata telah memenuhi standart yang telah di tentukan.

\subsubsection{Hasil Pengujian Agregat Kasar}

Pengujian terhadap agregat kasar yang dipakai dalam melakukan penelitian ini meliputi pengujian kadar air, kadar lumpur, berat volume, absropsi, berat jenis specific gravity, abrasi, agregat kasar. Hasil pengujian ini terdapat dalam Tabel 3.

Tabel 3. Spesifikasi Hasil Agregat Kasar.

\begin{tabular}{|c|c|c|c|c|}
\hline No & Karakteristik & Standar & Hasil Uji & Keterangan \\
\hline 1 & Kadar Air & $0.5 \%-2 \%$ & $1,41 \%$ & Memenuhi \\
\hline 2 & Kadar Lumpur & $0.2 \%-1 \%$ & $0,40 \%$ & Memenuhi \\
\hline \multirow[t]{3}{*}{3} & Berat Volume & & & \\
\hline & a. Lepas & $1.4-1.9 \mathrm{~kg} / \mathrm{liter}$ & 1,45 & Memenuhi \\
\hline & b. Padat & $1.4-1.9 \mathrm{~kg} / \mathrm{liter}$ & 1,59 & Memenuhi \\
\hline 4 & Absropsi & Maks 3\% & 2,91 & Memenuhi \\
\hline \multirow[t]{4}{*}{5} & Berat Jenis & & & \\
\hline & a. Bj Curah & $1.6-3.3$ & 2,40 & Memenuhi \\
\hline & $\begin{array}{l}\text { b. Bj Kering } \\
\text { Permukaan }\end{array}$ & $1.6-3.3$ & 2,47 & Memenuhi \\
\hline & c. Bj Semu & $1.6-3.3$ & 2,58 & Memenuhi \\
\hline 6 & Abrasi & Maks Keausan $40 \%$ & $29,14 \%$ & Memenuhi \\
\hline
\end{tabular}

Sumber : Analisa Perhitungan Spesifikasi Hasil Agregat Kasar.


Dari hasil tabel diatas menunjukkan bahwa nilai karakteristik agregat kasar dari kadar air, kadar lumpur, berat volume, absorpsi, berat jenis, abrasi, rata-rata telah memenuhi syarat dari standart yang telah di tentukan.

\subsection{Pengujian Slump}

Dari masing-masing adukan beton tersebut didapatkan nilai slump yang dapat dilihat pada Gambar 3.

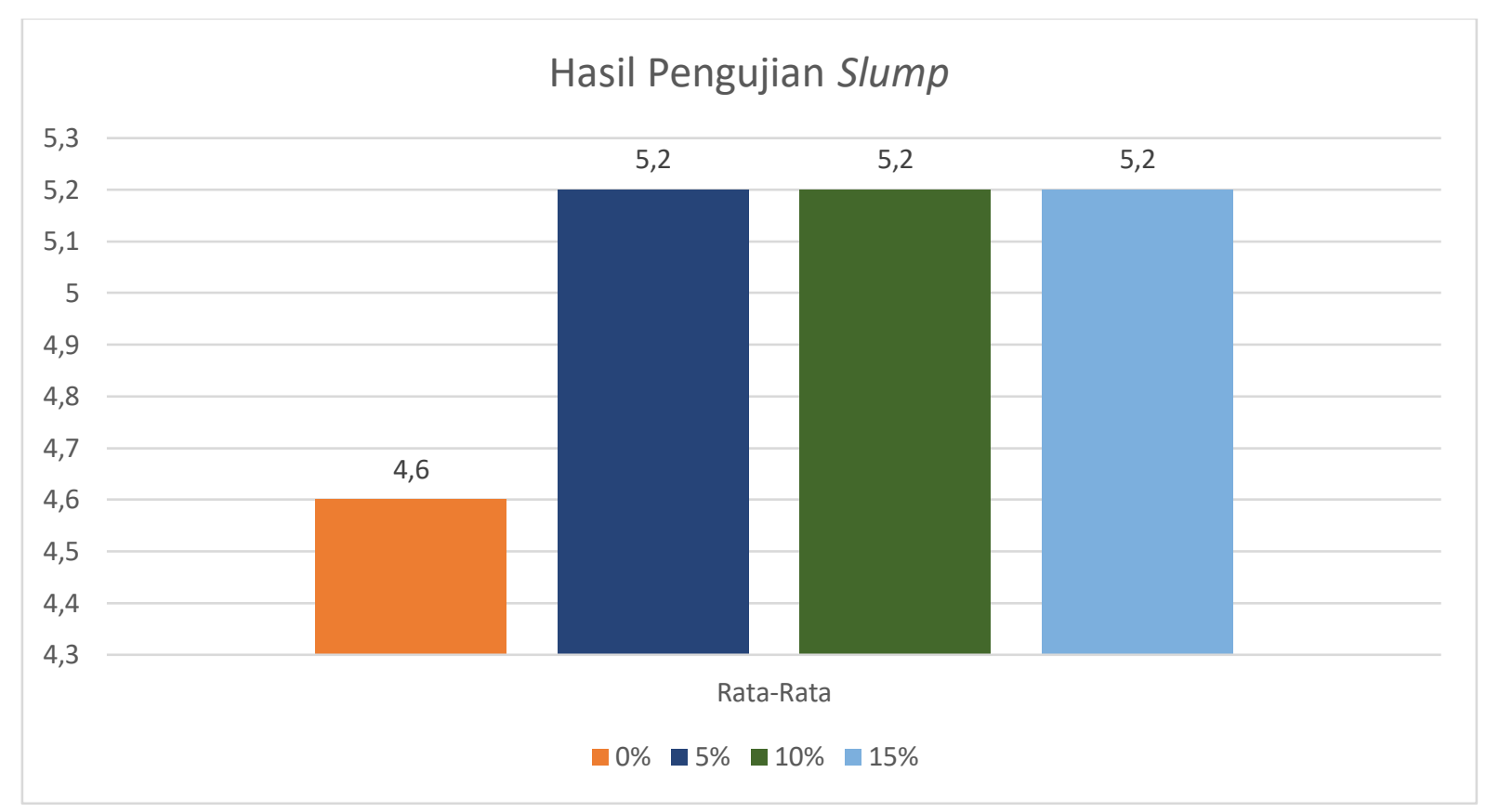

Sumber : Analisa Perhitungan Pengujian Slump.

Gambar 3. Hasil Pengujian Slump.

Dari hasil data diatas dapat di simpulkan bahwa nilai rata-rata slump dari beton normal $(4,6 \mathrm{~cm})$, beton $5 \%(5,2)$, beton $10 \%(5,2)$, beton $15 \%(5,2)$, telah memenuhi syarat dari standart yang telah ditentukan. 


\subsection{Pengujian Absorpsi}

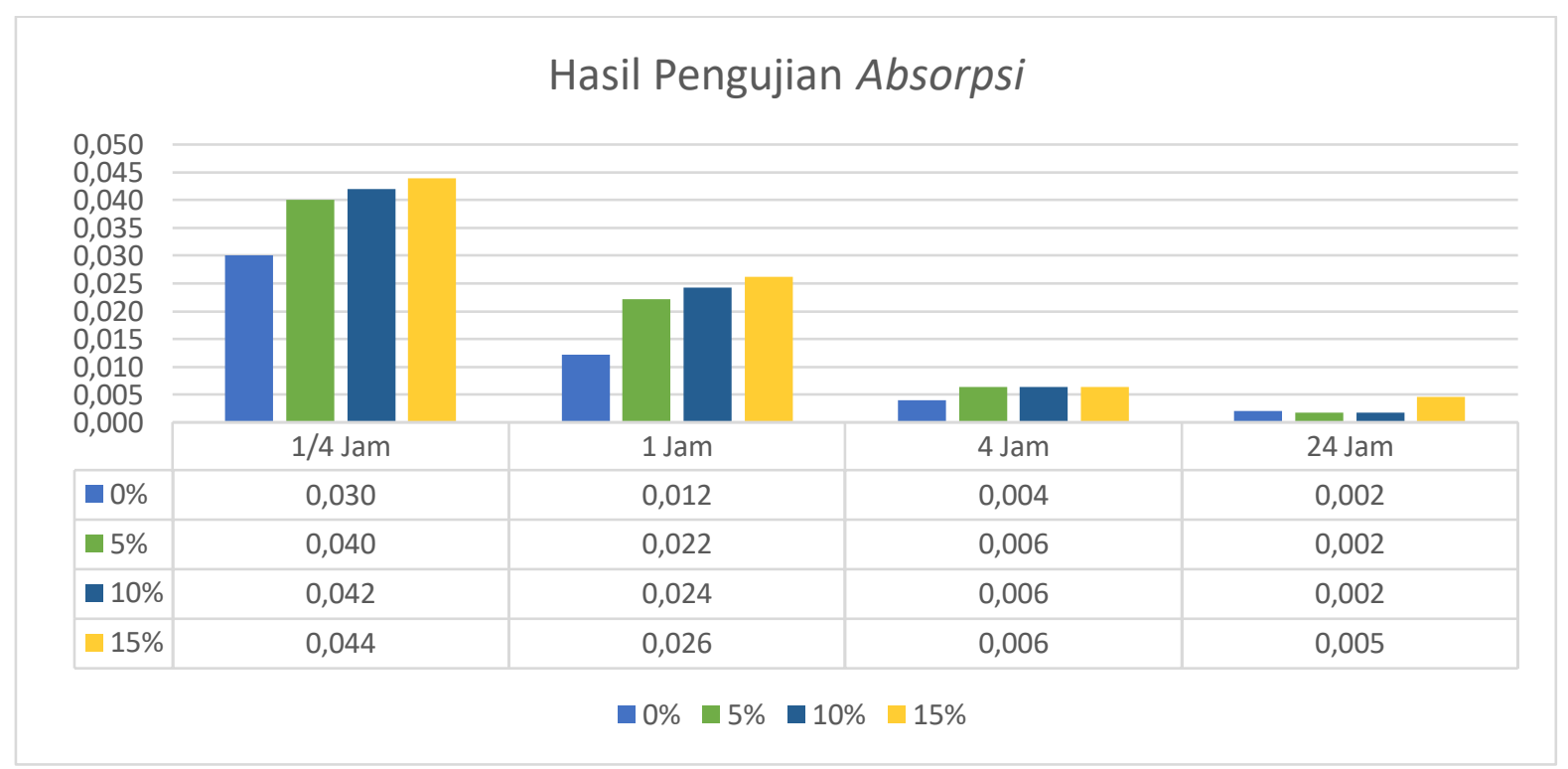

Sumber : Analisa Hasil Perhitungan Absorpsi.

Gambar 4. Hasil Pengujian Absorpsi.

Dari hasil data diatas dapat di simpulkan bahwa daya serap terbesar dari benda uji beton dengan waktu $1 / 4$ jam yaitu : beton normal $(0,030)$, beton $5 \%(0,040)$, beton $10 \%(0,042)$, beton $15 \%(0,044)$.

\subsection{Pengujian Kuat Tekan Beton}

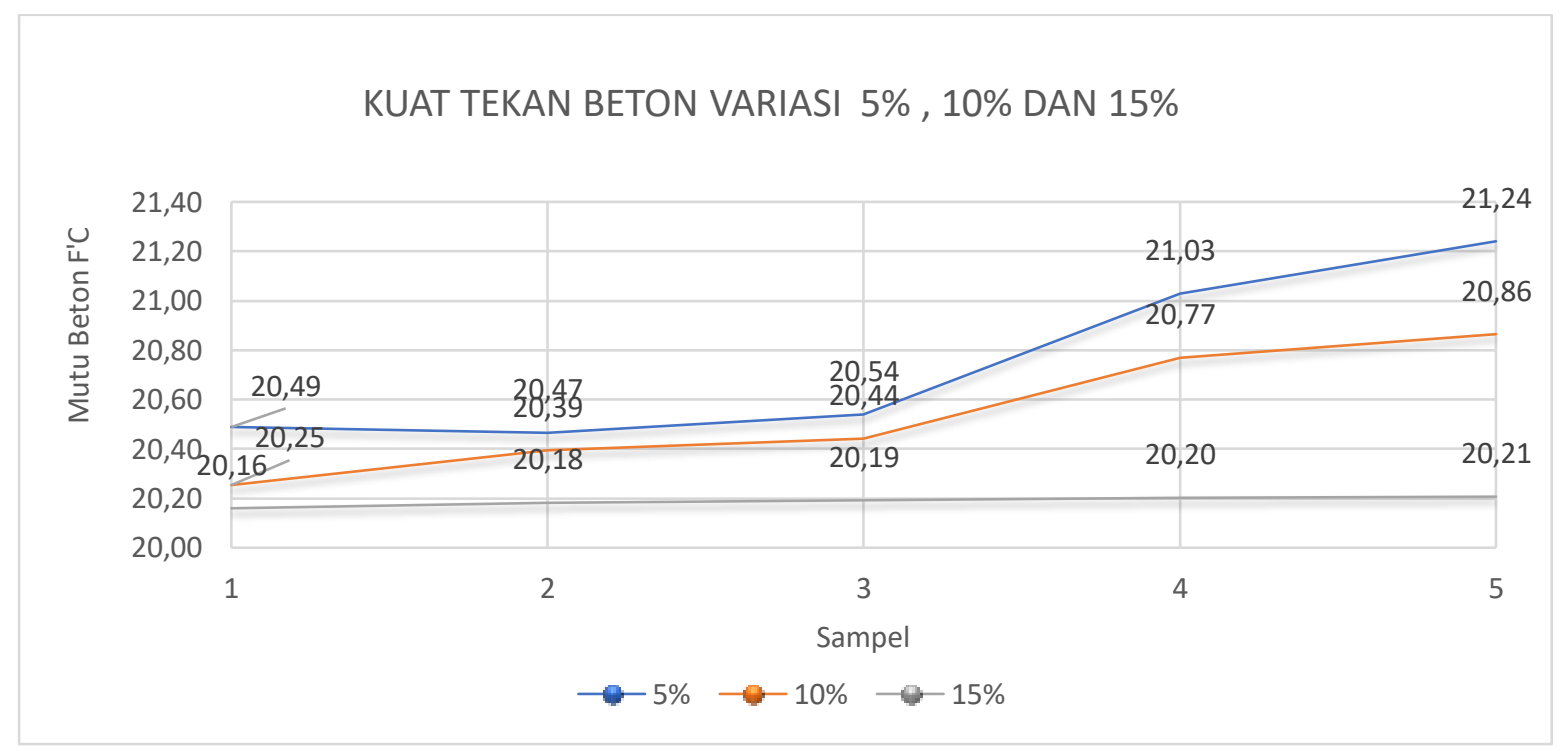

Sumber : Analisa Perhitungan Kuat Tekan Beton.

Gambar 5. Grafik Kuat Tekan Beton Variasi 5\%, 10\% dan 15\%.

Dari hasil data grafik diatas dapat disimpulkan bahwa nilai tertinggi kuat tekan beton diperoleh beton dengan kadar campuran biji genitri 5\% dengan hasil kuat tekan 21,24 mpa. 


\section{Kesimpulan dan Saran}

\subsection{Kesimpulan}

Dari penelitian ini dapat diambil beberapa kesimpulan yaitu :

1. Hasil pengujian Slump didapatkan nilai rata-rata beton genitri dengan persentase Variasi $0 \%=4,6 \mathrm{~cm}, 5 \%=5,2 \mathrm{~cm}, 10 \%=5,2 \mathrm{~cm}, 15 \%=5,2 \mathrm{~cm}$. Nilai rata-rata yang diperoleh : $5,05 \mathrm{~cm}$ (memenuhi)

2. Hasil Pengujian Kuat Tekan beton dengan genitri pada umur beton 28 hari memiliki ratarata yang berbeda yaitu BTN N: 21,00 (Mpa),BTN G 5\%: 20,17 (Mpa), BTN G 10\% : 20,12 (Mpa),BTN G 15\%: 19,53 (Mpa)

3. Hasil dari perhitungan berat volume mendapatkan nilai rata-rata 2,00 untuk nilai per sampel 0,400

Kesimpulan secara umum dari hasil penelitian beton menggunakan campuran biji genitri dengan persentase 5\%,10\%, 15\% rata-rata telah memenuhi nilai spesifikasi mutu beton 21,7 Mpa.

\subsection{Saran}

Berdasarkan hasil kesimpulan diatas, maka penulis memberikan saran, yaitu untuk penelitian selanjutnya yang terkait dengan pemanfaatan limbah biji genitri untuk persentase campuran agregat kasar alangkah baik di tambah lagi supaya mengetahui hasil dan kuat tekan yang berbeda, selanjutnya perlu dilakukanya perhitungan rencana anggaran biaya (RAB), dan perlu dilakukannya penelitian lebih lanjut guna memproleh hasil yang lebih maksimal. 


\section{Daftar Pustaka}

[1] P. P. Encik Junaidi Aprizal, "Pengaruh Partial Replacement Semen Portland Dengan Bentonite Terhadap Kuat Tekan Beton Berdasarkan Variasi Umur," Inersia, vol. 11, no. 1, pp. 67-78, 2015, doi: 10.21831/inersia.v11i1.9949.

[2] S. Winarto, "Pemanfaatan Serat Ijuk Sebagai Material Campuran Dalam Beton Untuk Meningkatkan Kemampuan Beton Menahan Beban Tekan Studi Kasus: Pembangunan Homestay Singonegaran Kediri," UKaRsT, vol. 1, no. 1, pp. 1-10, 2017.

[3] Y. Ismida, M. Amin, Hamdani, U. Amna, Fazri, and C. Akbar, "Experimental Study of Heat-absorbent Foam Concrete Wall based Macro-encapsulation of Beef Tallow/Damar Gum in Building," IOP Conf. Ser. Mater. Sci. Eng., vol. 536, no. 1, 2019, doi: 10.1088/1757-899X/536/1/012137.

[4] H. Pratikto, "Penelitian Kuat Uji Tekan Beton Dengan Memanfaatkan Limbah Beton Yang Tidak Terpakai," UKaRsT, vol. 1, no. 2, p. 21, 2017, doi: 10.30737/ukarst.v1i2.411.

[5] D. V. Kim, L. N. Cong, L. T. Van, and S. I. Bazhenova, "Foamed concrete containing various amounts of organic-mineral additives," J. Phys. Conf. Ser., vol. 1425, no. 1, 2020, doi: 10.1088/1742-6596/1425/1/012199.

[6] Setiawan and A. A. Pratama, "Pengaruh Substitusi Agregat Kasar Dengan Biji Ganitri Pada Beton Ringan,” Diss Univ. Pendidik. Indones., 2014.

[7] A. I. Candra and E. Siswanto, "Rekayasa Job Mix Beton Ringan Menggunakan Hydroton dan Master Ease 5010," CIVILLa, vol. 3, no. 2, pp. 162-165, 2018.

[8] G. H. Barbhuiya, M. A. Moiz, S. D. Hasan, and M. M. Zaheer, "Effects of the nanosilica addition on cement concrete: A review," Mater. Today Proc., 2020, doi: 10.1016/j.matpr.2020.02.143.

[9] Sumiati, Mahmuda, Sukarman, S. Indra, and D. Prabudi, "The Utilization of Crushed Clay Brick as Coarse Aggregate on Eco-Green Lightweight Foamed Concrete," J. Phys. Conf. Ser., vol. 1500, no. 1, 2020, doi: 10.1088/1742-6596/1500/1/012070.

[10] C. Gunasekara, M. Sandanayake, Z. Zhou, D. W. Law, and S. Setunge, "Effect of nanosilica addition into high volume fly ash-hydrated lime blended concrete," Constr. Build. Mater., vol. 253, p. 119205, 2020, doi: 10.1016/j.conbuildmat.2020.119205.

[11] Y. Haryanto, G. H. Sudibyo, and N. G. Wariyatno, "Experimental Study on the Properties of Artificial Lightweight Aggregate Concrete Reinforced with Carpet Waste Fiber,” IOP Conf. Ser. Mater. Sci. Eng., vol. 371, no. 1, 2018, doi: 10.1088/1757- 
899X/371/1/012006.

[12] V. Gokulnath, B. Ramesh, and R. Raghuraman, "Study on the effect of M-sand in self compacting concrete with addition of steel fibers," Mater. Today Proc., vol. 22, pp. 843846, 2020, doi: 10.1016/j.matpr.2019.11.029.

[13] A. Faslih, I. Kadir, and M. Z. Umar, "Practical production of lightweight concrete floor tiles," IOP Conf. Ser. Earth Environ. Sci., vol. 419, no. 1, 2020, doi: 10.1088/17551315/419/1/012150.

[14] P. R. T. Naibaho, "Panjang Penyaluran Carbon Fibre pada Perkuat Struktur Beton di Daerah Tumpuan,” Diss Univ. Indones., 2008.

[15] S. S. S-04-1989-F, "Material Pembentukan Beton," Tek. Sipil Politek. Negeri Sriwij., vol. 53, no. 9, pp. 1689-1699, 2013, doi: 10.1017/CBO9781107415324.004.

[16] X. Liu, Q. Sun, Y. Yuan, and L. Taerwe, "Comparison of the structural behavior of reinforced concrete tunnel segments with steel fiber and synthetic fiber addition," Tunn. Undergr. Sp. Technol, vol. 103, no. March, p. 103506, 2020, doi: 10.1016/j.tust.2020.103506.

[17] Badan Standardisasi Nasional Indonesia, "Semen Portland SNI 15-2049-2004," BSN, Jakarta, 2004.

[18] Nafratilova, Hilda, A. Sufadjari, and Nurcahyati, “Aktivitas Antifungsi Ekstrak Etanol Biji Ganitri (Elaeocarpus Sphaericus Schum) Terhadap Pertumbuhan Fungi Aspergillus flavus," J. Biosense, vol. 1, no. 1, pp. 1-14, 2018.

[19] P. A. Siwi, "Penelusuran Penyebab Resistensi Antibiotika Dari Bakteri Multiresisten Antibiotik (ISOLAT MG dan WK 45)," Diss Univ. Muhamadiyah Purwokerto, 2015.

[20] M. Qin, Q. Gui, and K. Li, "Study on durability indicators for structural concretes," 14th Int. Congr. Chem. Cem., no. March, 2015.

[21] A. A. Torres-Acosta and L. Alejandra Díaz-Cruz, "Concrete durability enhancement from nopal (opuntia ficus-indica) additions," Constr. Build. Mater., vol. 243, p. 118170, 2020, doi: 10.1016/j.conbuildmat.2020.118170. 